\title{
Arsenic Contamination of Ground and Drinking Water in Vietnam: A Human Health Threat
}

\author{
Michael Berg, ${ }^{*}, \dagger$ Hong Con Tran, Thi Chuyen Nguyen, $\ddagger$ Hung Viet Pham, \\ Roland Schertenleib,$^{\dagger}$ and Walter Giger ${ }^{\dagger}$
}

May 7, 2001

Revised Manuscript ES010027Y

$\dagger$ Swiss Federal Institute for Environmental Science and Technology (EAWAG),
\[ \text { CH-8600 Dübendorf, Switzerland } \]
$\ddagger$ Centre of Environmental Chemistry, Hanoi University of Science, Hanoi, Vietnam

*Corresponding author. Phone: +41-1-823 50 78; Fax: +41-1-823 5028

E-mail: michael.berg@eawag.ch

This document is the Accepted Manuscript version of a Published Work that appeared in final form in Environmental Science and Technology, copyright (C) American Chemical Society after peer review and technical editing by the publisher. To access the final edited and published work see http://doi.org/10.1021/es010027y 


\section{Abstract}

This is the first publication on arsenic contamination of the Red River alluvial tract in the city of Hanoi and in the surrounding rural districts. Due to naturally occurring organic matter in the sediments, the groundwaters are anoxic and rich in iron. With an average arsenic concentration of $159 \mu \mathrm{g} / \mathrm{L}$ the contamination levels varied from $1-3,050 \mu \mathrm{g} / \mathrm{L}$ in rural groundwater samples from private small-scale tubewells. In a highly affected rural area, the groundwater used directly as drinking water had an average concentration of $430 \mu \mathrm{g} / \mathrm{L}$ arsenic. Analysis of raw groundwater pumped from the lower aquifer for the Hanoi water supply yielded arsenic levels of $240-320 \mu \mathrm{g} / \mathrm{L}$ in three of eight treatment plants and 37-82 $\mu \mathrm{g} / \mathrm{L}$ in another five plants. Aeration and sand filtration that are applied in the treatment plants for iron removal lowered the arsenic concentrations to lower levels of $25-91 \mu \mathrm{g} / \mathrm{L}$ but $50 \%$ remained above the Vietnamese Standard of $50 \mu \mathrm{g} / \mathrm{L}$. Extracts of sediment samples from five bore cores showed a correlation of arsenic and iron contents $\left(r^{2} 0.700, n=64\right)$. The arsenic in the sediments may be associated with iron oxyhydroxides and released to the groundwater by reductive dissolution of iron. Oxidation of sulfide phases could also release arsenic to the groundwater but sulfur concentrations in sediments were below $1 \mathrm{mg} / \mathrm{g}$. The high arsenic concentrations found in the tubewells (48\% above $50 \mu \mathrm{g} / \mathrm{L}, 20 \%$ above 150 $\mu \mathrm{g} / \mathrm{L})$ indicate that several million people consuming untreated groundwater might be at a considerable risk of chronic arsenic poisoning. 


\section{Introduction}

Natural contamination of groundwater by arsenic has become a crucial water quality problem in many parts of the world, particularly in the Bengal delta (Bangladesh and West Bengal, India) (1-8). Smith et al. (9) have stated that "the contamination of groundwater by arsenic in Bangladesh is the largest poisoning of a population in history, with millions of people exposed". In the U.S., the Environmental Protection Agency has proposed lowering the maximum contaminant level for arsenic in drinking water from $50 \mu \mathrm{g} / \mathrm{L}$ to $10 \mu \mathrm{g} / \mathrm{L}$ but the feasibility of the proposed standard is currently being evaluated (10). The European maximum admissible concentration and the World Health Organization guideline for arsenic in drinking water are both set at $10 \mu \mathrm{g} / \mathrm{L}$. On the other hand, developing countries are struggling to find and implement measures to reach standards of $50 \mu \mathrm{g} / \mathrm{L}$ in arsenic affected areas.

The Vietnamese capital Hanoi is situated at the upper end of the 11,000 $\mathrm{km}^{2}$ Red River delta of northern Vietnam, which is inhabited by 11 million people and is one of the most populous areas in the world. Together with the Mekong delta, the Red River delta (Bac Bo plain) has become one of the most productive agricultural regions of South East Asia. The rural population is growing rapidly and has, in the last 5-7 years, moved away from using surface water or water from shallow dug wells as sources for drinking water in favor of groundwater pumped from individual private (family based) tubewells. Groundwater exploitation in the city of Hanoi began 90 years ago. Today, eight major well fields supply water to city treatment facilities which process $500,000 \mathrm{~m}^{3}$ of water per day (11). 
The Red River basin stretches from N $20^{\circ} 00^{\prime}$ to $\mathrm{N} 25^{\circ} 30^{\prime}$ and $\mathrm{E} 100^{\circ} 00^{\prime}$ to $\mathrm{E} 107^{\circ} 10^{\prime}$ and is bounded by the Truong Giang and Chau Giang River basins in the north, the Mekong River in the west, the Ma River basin in the south and the Gulf of Tonkin in the east. The Red River basin has a gross catchment area of $169,000 \mathrm{~km}^{2}(12)$, and a total length of $1,150 \mathrm{~km}$. It is dominated by tropical monsoon climate and is subject to rainy (May-September) and dry seasons (October-April). The average temperature in Hanoi is $23.4^{\circ} \mathrm{C}$ and the average rainfall is $1,800 \mathrm{~mm} /$ year (13). During the rainy season, the Red River in Hanoi may reach a water discharge of $9,500 \mathrm{~m}^{3}$ per second (14). The long-term average flow is $3,740 \mathrm{~m}^{3} / \mathrm{s}(13)$ but the river volume is highly variable throughout the year. The River carries huge quantities of silt, rich in iron oxide, because of the large proportion of easily crumbled soil in its basin (14). The suspended solid load may reach over $6 \mathrm{~kg} / \mathrm{m}^{3}$ in the lower Red River during food seasons when over $90 \%$ of the annual load is transported (13).

The Bac Bo plain is a flat area with a ground level of 5-8 $\mathrm{m}$ above mean sea level. It has a complicated geological history with up and down movements, transgressions, erosion and stream activities that formed the alluvial sediments $(13,15)$. The result of these geological processes is a relatively thick Quaternary formation (50-90 $\mathrm{m}$ in Hanoi) with loose and altering sediment beds (13), often containing organic material(15). In general, the Quaternary formation can be divided into two sequences, (i) the upper, composed of fine sediment clay, sandy clay and fine sand, and (ii) the lower part, containing gravel with cobbles and coarse sand $(13,15)$. The Quaternary sediments are underlain by Tertiary deposits of Neogene age that are composed of conglomerate sandstone, clay and siltstone (13). In total the deposits exceed $400 \mathrm{~m}$. More detailed information can be found in references $(13,16)$. 
Naturally anoxic conditions in the aquifers are due to peat deposits (15)), and, consequently, the groundwaters contain large amounts of iron and manganese that are removed in the Hanoi drinking water plants by aeration and sand filtration (13). The urban water treatment plants exclusively exploit the lower aquifers at 30-70 $\mathrm{m}$ depth, whereas private tubewells predominantly pump groundwater from the upper aquifer at 12-45 m depth (11).

Based on geological analogies to the Bengal delta (i.e., relatively young alluvial sediments and anoxic groundwater) and similar composition of the groundwater as in Bangladesh (17) we anticipated elevated arsenic concentrations in the aquifers of the Red River basin. Thus, the objective of our study was to survey arsenic levels in the aquifers of the region around Hanoi. Our initial overview provides preliminary conclusions regarding the sources and mechanisms for arsenic release to the groundwater that have resulted in the high arsenic concentrations we have recently discovered in the ground and drinking waters of the Hanoi area. 


\section{Methods}

Sample Collection. Figure 1 shows the sampling locations for raw groundwater and of drinking water plants in Hanoi and the surrounding rural districts A-D. Based on a projected density of one sample per $10 \mathrm{~km}^{2}$, we randomly selected 68 private tubewells of the districts A-D over the $700 \mathrm{~km}^{2}$ area. Groundwater samples from the tubewells were collected three times in September 1999, December 1999, and again in May 2000. Prior to sampling, the tubewells were flushed with 2-3 tubewell volumes of groundwater (e.g. $70 \mathrm{~L}$ for $20 \mathrm{~m}$ depth, tube i.d. $4 \mathrm{~cm}$ ). The generally crystal clear water samples were collected in $50-\mathrm{mL}$ polypropylene flasks and acidified with $1 \mathrm{~mL}$ concentrated nitric acid. The few turbid samples (i.e. less than $5 \%)$ were filtered $(0.45 \mu \mathrm{m})$ in the laboratory and acidified thereafter. In water treatment plants, mixed raw groundwater derived from the operating pumps of the wellfields were sampled before aeration. Treated drinking water was collected from the storage tanks after chlorination. Tap water was sampled from randomly selected households that are supplied with treated drinking water from treatment plants. Water samples for tritium measurements were sampled directly at the wellheads of pumps in drinking water plants (Mai Dich pump H4, Ha Dinh pump 8, Phap Van pump 2) and in the Henninger Beer factory (pump 2) in pinched-off copper tubes (18).

Sediment bore cores of 12-40 m depth were drilled in July 2000 in each of the four rural districts and in Hanoi next to the Luong Yen well field. The bore core locations are marked in Figure 1a. Visually distinct vertical sections of the freshly drilled bore cores were sampled on-site at 1-2 meters interval and $20 \mathrm{~g}$ of the wet sediment were collected in polypropylene bags, which were sealed airtight on the spot. The bore cores were photographed and the layers visually classified. Water and sediment samples were stored at $4{ }^{\circ} \mathrm{C}$. 
Water Analysis. Water samples were analyzed for total arsenic and total iron at the Hanoi University of Science by atomic absorption spectroscopy (AAS) using a Shimadzu AA-6800 instrument (Kyoto, Japan). For arsenic measurements, an on-line hydride generation device was coupled to the AAS (HG-AAS). The instrument was calibrated from $1-6 \mu \mathrm{g} / \mathrm{L}$ and the samples were diluted with de-ionized and distilled water (sometimes several times) to this concentration range. For comparison, $20 \%$ of the samples were sent to Switzerland and total arsenic was analyzed by an independent contract laboratory with a hydride generation-atomic fluorescence spectroscopy (HG-AFS) system from PS Analytical (Kent, England; calibration range $2-50 \mu \mathrm{g} / \mathrm{L})$. Tritium was analyzed by mass spectrometry as described elsewhere (18).

Sediment Analysis. Sediment samples were freeze-dried, extracted and analyzed at EAWAG. The sulfur content was evaluated in dry sediments with X-ray fluorescence by the Swiss Federal Laboratories for Material Testing and Research. Aliquots of $100 \mathrm{mg}$ dried sediment were extracted in Teflon cups with a microwave extraction device (1200 mega, MLS GmbH, Leutkirch, Germany) using a solution of $2 \mathrm{~mL}$ water, $4 \mathrm{~mL}$ concentrated nitric acid (65\% suprapur, Merck) and $1 \mathrm{~mL}$ hydrogen peroxide (30\% suprapur, Merck). The following microwave sequence was applied: $250 \mathrm{~W}(10 \mathrm{~min}), 0 \mathrm{~W}(2 \mathrm{~min}), 600 \mathrm{~W}(4 \mathrm{~min}), 0$ $\mathrm{W}$ (1 min), $400 \mathrm{~W}(7 \mathrm{~min}), 60 \mathrm{~min}$ vent/cool down. Before analysis, the sediment extracts were diluted to $50 \mathrm{~mL}$ with purified water (Nanopure water purification device, Skan, Basel, Switzerland). Total arsenic in sediment extracts was determined by HG-AFS (PS Analytical, Kent, England; calibration range $0.5-20 \mu \mathrm{g} / \mathrm{L}$ ) and total iron and manganese were measured by inductively coupled plasma-optical emission spectroscopy (ICP-OES, Spectroflame, Spectro, Kleve, Germany; calibration range $0.5-40 \mathrm{mg} / \mathrm{L} \mathrm{Fe}$ and $0.5-4 \mathrm{mg} / \mathrm{L} \mathrm{Mn}$ ). The total organic carbon (TOC) and total organic nitrogen (TON) content in the sediment samples 
were measured by thermic oxidation with a CHN analyzer (EA 1108, Carlo Erba, Milano, Italy).

Quality Assurance. As mentioned above, 20\% of the water samples were sent to Switzerland for quality assurance. The arsenic concentrations determined by a Swiss contract laboratory and at the Hanoi University of Science agreed within $20 \%$ deviation. To further assure the quality of the measurements, recoveries were determined before every sample series in certified water samples (SPS-SW1, Merck VI standard) or in reference sediments (Buffalo River Sediment 2704, IMEP-14, BCR-320). Recoveries in water samples were in the range of $92-109 \%$ (As), and $90-110 \%$ (Fe, Mn). With the microwave extraction method

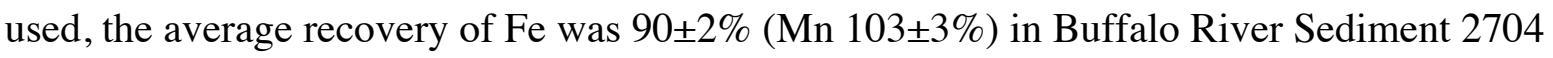
and $92 \pm 3 \%$ in IMEP-14. Although clay minerals are not fully digested with the microwave extraction method, the Fe recoveries obtained for the reference materials are in an acceptable range. Confirmatory measurements of total arsenic in sediment samples were carried out in the solid sediments with semi-quantitative wavelength dispersive X-ray fluorescence (WDXRF) by the Swiss Federal Laboratories for Material Testing and Research. The WD-XRF results were calculated from arsenic impulse rates $(\mathrm{PbL} \alpha / \mathrm{PbL} \beta$ corrected) with a fitted one point calibration derived from the certified total arsenic concentration in BCR-320 (77 $\mu \mathrm{g} / \mathrm{g}$ As) reference material. The estimated inaccuracy is $\pm 5 \mu \mathrm{g} / \mathrm{g}$. 


\section{Results and Discussion}

Arsenic Concentrations in Upper and Lower Aquifers. We sampled 68 private tubewells in the rural districts and the eight major drinking water plants of Hanoi. Figure 1a shows the arsenic concentrations measured in samples collected in September 1999 from the upper aquifers in tubewells of the rural districts. Table 1 summarizes the arsenic concentrations measured in three sample series of the 68 private tubewells (see Supporting Information for the full database). The majority (72\%) of the tubewells yielded arsenic concentrations above the current WHO guideline of $10 \mu \mathrm{g} / \mathrm{L}$ and the concentrations varied greatly $(1-3,050 \mu \mathrm{g} / \mathrm{L})$ within the studied area. In district D $89 \%$ of the arsenic concentrations exceeded the Vietnamese standard of $50 \mu \mathrm{g} / \mathrm{L}$. In the southern parts of the districts $\mathrm{C}$ and D high arsenic concentrations of $1,000-3,000 \mu \mathrm{g} / \mathrm{L}$ were measured on both sides of the Red River. These results indicate that the sources of contamination are distributed over a large area.

Raw groundwaters pumped for the public water supply from the lower aquifer and treated waters from the eight Hanoi water treatment plants were sampled seven times between April 1999 and July 2000 (7 series of 16 samples). The concentrations in September 1999, depicted as split rectangles in Figure 1b, show that two of the analyzed raw groundwaters contained more than $300 \mu \mathrm{g} / \mathrm{L}$ arsenic. Figure 2 summarizes the arsenic concentrations measured in raw groundwater and in treated water of the Hanoi water treatment plants during the 15-month study period. The full database is provided as Supporting Information. Concentrations found in raw groundwater $(15-430 \mu \mathrm{g} / \mathrm{L})$ were substantially reduced in treated water yet average concentrations of 25-91 $\mu \mathrm{g} / \mathrm{L}$ remained (range 11-190 $\mu \mathrm{g} / \mathrm{L}$ ). Interestingly, 27 of the 29 tap water samples collected at individual homes (see Figure 1b) contained arsenic concentrations below $50 \mu \mathrm{g} / \mathrm{L}$ (range $7-82 \mu \mathrm{g} / \mathrm{L}$, average $31 \mu \mathrm{g} / \mathrm{L}$ ), suggesting that additional arsenic 
removal may be occurring in the distribution system, possibly by adsorption to iron oxide surfaces in the pipes. Under the conditions of piped supply water (average $\mathrm{pH} 7.30$, Fe 1-13 $\mu \mathrm{M}$, As $\sim 1 \mu \mathrm{M}$ ), sorption of arsenic is plausible (19).

Arsenic Concentrations in Sediments. In July 2000 we sampled sediments from freshly drilled bore cores of 12-40 m depth (mainly upper aquifer). The locations of the five cores are marked in Figure 1a. The cores 1-4 were drilled next to groundwater monitoring wells of the Vietnam Hydrogeological Division II, and water from these wells were sampled concurrently. Core 5 was drilled in urban Hanoi next to the Luong Yen water plant (no. V in Figure 1a). We attempted to measure the sulfur content in the dried sediment material by Xray analysis, however, only traces of sulfur below the quantification limit were detected (LOQ $\sim 1 \mathrm{mg} / \mathrm{g}$ ). Based on the low sulfur concentrations we inferred that arsenic containing sulfide minerals are not very abundant in the investigated sediments.

Extracted arsenic and iron concentrations varied with depth in stratigraphically different sediment layers. Peak arsenic concentrations of 6-33 mg/kg were primarily associated with brown to black-brown clay layers, followed by gray clay $(2-12 \mathrm{mg} / \mathrm{kg})$ and brown to gray sand $(0.6-5 \mathrm{mg} / \mathrm{kg})$. Figure 3 shows the correlation $\left(\mathrm{r}^{2} 0.700\right.$, two outlyers excluded $)$ of extracted arsenic with extracted iron, suggesting that arsenic could be associated with iron phases. The extreme outlyer marked by an open diamond in Figure 3 was measured in a peat layer. The full database listing As, Fe, Mn, TOC, and TON values measured in the sediment samples is provided as Supporting Information. The arsenic concentration pattern in the sediments was confirmed with WD-XRF measurements, although the total arsenic contents obtained by WD-XRF were somewhat higher than the extracted arsenic measured with AFS analysis (average difference $3.8 \mu \mathrm{g} / \mathrm{g}$ ). This difference might be due to incomplete extraction 
of arsenic from clay minerals but should not be over-interpreted because WD-XRF values are subject to an inaccuracy of $\pm 5 \mu \mathrm{g} / \mathrm{g}$ (see Methods section). No correlation was observed between sediment-bound arsenic and dissolved arsenic in groundwater collected from the corresponding depth of the adjacent monitoring wells (data not shown).

Aspects of Arsenic in Anoxic Groundwater. Although there is no evidence for an anthropogenic origin of arsenic in the subsurface in and around Hanoi, the possibility of pollution by landfill leakage, agricultural fertilizers, or mining wastes carried by the Red River cannot be excluded. However, the widespread arsenic occurrence in the investigated aquifers points to natural geogenic sources similar to the situation in the Ganges delta $(1,3-5$, $7,8,20)$. Sediment-bound arsenic most probably originates from erosion and weathering processes, which result in the fluvial transport and sedimentation of arsenic-enriched iron oxyhydroxides (21-23). Several studies $(1,7,8,20,24-26)$ have suggested that elevated arsenic levels in anoxic groundwater are caused by reductive dissolution of arsenic-rich iron oxyhydroxides occurring as dispersed phases in the aquifer rocks. Under oxic conditions, the release of arsenic from sulfide phases such as arsenian pyrite (naturally occurring $(5,26)$, in deposits of gold mining wastes (27)), in pegmatite-hosted arsenic sulfides (21), or from a sulfide-bearing secondary cement horizon (28) have been reported. In anoxic environments sulfide minerals including arsenopyrite can incorporate arsenic and are therefore considered a sink for arsenic $(8,26)$. Kim et al. (29) hypothesized that bicarbonate ions cause the leaching of arsenic into groundwater by carbonation of arsenic sulfide minerals. However, the process would not be significant at the bicarbonate concentrations commonly found in the Hanoi aquifers $(<10-20 \mathrm{mM})$. 
The anoxic conditions in the Red River sediments are probably maintained by natural organic matter (NOM) present in the subsurface $(15,30,31)$. Using data obtained from the Vietnam Hydrogeological Division II, Trafford et al. (15) have mapped peat layers in the districts B and $\mathrm{D}$ and showed that these layers are very abundant and are often over $10 \mathrm{~m}$ thick in district D. In the upper $8 \mathrm{~m}$ of the bore cores 2 and 3 we have found peat layers (2-3 $\mathrm{m}$ thick) with NOM concentrations of up to $15 \%$ total organic carbon. Dissolved oxygen is rapidly consumed by microbiological oxidation of NOM, resulting in the formation of bicarbonate and inorganic nitrogen species. This is consistent with the high alkalinity $(31-810 \mathrm{mg} / \mathrm{L}$ ( 15 , $32))$ and high nitrogen concentrations $(10-48 \mathrm{mg} \mathrm{N} / \mathrm{L}(15,30))$ measured in the studied groundwaters. Inorganic nitrogen was mainly found in the reduced form of ammonium that reached particularly high levels of $48 \mathrm{mg} / \mathrm{L}(15)$ in the severely arsenic contaminated district D. These findings suggest that the oxidation of the buried peat material is responsible for the highly reducing conditions in the aquifers. As a result of the low redox potential, As(V) is most likely reduced to the more mobile $\operatorname{As}(\mathrm{III})(19,24,31)$.

Geological and Hydrogeological Conditions. In order to explain the significantly different arsenic levels of district A and district D (Figure 1a), the different geological settings and actual hydrogeological conditions of these areas must be considered (see also Introduction). The geology of the Red River delta is complex with considerable variation in lithology within short distances (15). The sediments in district A (predominantly of Pleistocene age) are not as thick as in the other districts and form mainly one aquifer at 10-25 m depth (11). The other districts have sediments of both Pleistocene and Holocene age, with the latter being partly derived from postglacial marine transgressions $(11,15)$. Due to frequent riverbed migrations, the aquifers are not fully separated and are in some locations connected through sand lenses (15). In an approximately $10 \mathrm{~km}$ wide zone along the Red River the upper and 
the lower aquifers are today mainly recharged from the river, and, the rest of the lower aquifer mainly by vertical percolation from the upper aquifer (13). Even without the pumping of groundwater, recharge in the upper two aquifers can partly originate from Red River bank filtration (15). However, Hanoi's high water demand is causing a significant drawdown of the groundwater. This is particularly severe in the districts B and D where depression cones go down as far as $30 \mathrm{~m}$ (11). As a consequence, the ammonium contamination increased significantly in district D from 1992-1995 (33), and, land subsidence of more than 20 $\mathrm{mm} /$ year has been reported for many years in the Hanoi area $(13,34)$. The authors of reference (13) established a groundwater flow model for the districts B and D and attributed the recharge of the lower aquifer to $30-35 \%$ from surface water bodies, $60-65 \%$ to vertical percolation, and 2-3\% to lateral inflow.

For this study we have measured tritium concentrations in raw groundwater samples from the districts A, B, and D. The samples collected in April 1999 in the water treatment plants I, VI, and VIII (districts B and D, see Figure 1, Figure 2 and Methods) yielded ${ }^{3} \mathrm{H}$ concentrations of $1.2 \pm 0.3,1.8 \pm 0.3$, and $1.9 \pm 0.3$ tritium units, respectively, Comparing these data with the (nearest) Bangkok station of the IAEA/WMO network shows that the likely period of infiltration lies between 1985-1995. If Red River water is assumed to be the only source of recharge, considerable groundwater flow velocities on the order of meters per day can be inferred. A very different situation was found in district A where the aquifers are only slightly disturbed. The groundwater sample collected from the Henninger Beer factory $(8 \mathrm{~km}$ north of the Red River in district A) had a tritium unit of only 0.1 , indicating that this water is much older (i.e., more than 50 years). 
Spatial and Seasonal Variations of Arsenic Concentrations. Extremely high arsenic concentrations were found in district $\mathrm{D}$, an area of substantial groundwater abstraction. There is evidence that the groundwater tables in this area have been drastically lowered which would result in a downshift of the redox boundaries. Thus, peat layers that were formerly water saturated and anoxic can be expected to be exposed to oxygen in the unsaturated zone. If the (partial) oxidation of peat were accelerated, downward migration of NOM-rich leachates could maintain anoxia in the aquifers below the peat layers. We suggest the high groundwater abstraction from peat-rich aquifers may enhance dissolution of arsenic-rich iron oxyhydroxides and, thus, lead to increased arsenic concentrations in the upper aquifer of district D. However, the release of arsenic from the oxidation of arsenic-bearing sulfide minerals must also be considered. More detailed investigations are necessary to understand the arsenic pollution mechanism(s) in the Hanoi area.

In addition to the regional differences, seasonal variations of arsenic concentrations have been observed in the upper aquifers. We have analyzed the same 68 tubewells in September 1999, December 1999, and again in May 2000. As shown in Table 2 the highest arsenic concentrations occurred at the transition of the rainy season to the dry season (September, December) and the lowest at the end of the dry season (May). These variations may be related to the pronounced seasonality of the Red River discharge. The average seasonal difference of the water level is $10 \mathrm{~m}(8.9 \mathrm{~m}$ in 1999), which causes significant fluctuations in the groundwater table (11). Notably, the seasonal variation was most pronounced in the district A (see Table 2) which experiences higher groundwater table fluctuations than the intensely-pumped aquifers in district $\mathrm{D}$. The variations in redox conditions associated with fluctuating groundwater levels could enhance release of arsenic to the groundwater through either reductive or oxidative mechanisms. Our database is undoubtedly too limited to draw 
conclusions regarding the processes governing the observed variability in arsenic concentrations.

Health Aspects. To the best of our knowledge, symptoms of chronic arsenic exposure have not yet been reported in Vietnam despite several million Vietnamese may be consuming arsenic-rich drinking water $(>50 \mu \mathrm{g} / \mathrm{L})$ and are therefore at risk of chronic arsenic poisoning. Figure 4 illustrates the cumulative frequency distribution of the arsenic concentration ranges measured in this study. In the four district A-D, 25-90\% (average 48\%, n=196) of the investigated groundwaters exceed the Vietnamese arsenic standard of $50 \mu \mathrm{g} / \mathrm{L}$ and $50-98 \%$ (average $72 \%$ ) were above the WHO guideline value of $10 \mu \mathrm{g} / \mathrm{L}$. Thus the Hanoi area and possibly larger areas of the Red River delta may be as severely affected as Bangladesh (25\% above $50 \mu \mathrm{g} / \mathrm{L}, \mathrm{n}=3534)(7)$.

Especially the alarmingly high concentrations in the upper aquifer of district $\mathrm{D}$ raise the question of why arsenicosis has not been detected in this area so far. The groundwater pumped through the family-based tubewells are often used directly as drinking water. However, the first private tubewells were installed only 7 years ago and the first cases of chronic arsenic poisoning from ingestion of contaminated water are typically observed only after 5-10 years of exposure $(35,36)$. Furthermore, the early manifestations are difficult to diagnose particularly in the absence of awareness of potential problems (37). Consequently, we urgently propose further and thorough evaluation of the extent of the ground and drinking water contamination by arsenic and early mitigation actions in order to reduce the risk of chronic arsenic poisoning of millions of people in Vietnam. 


\section{Acknowledgments}

This project has substantially been funded by the Swiss Agency for Development and Cooperation (SDC) in the framework of the Swiss-Vietnamese cooperation project ESTNV (Environmental Science and Technology in Northern Vietnam). We thank Nguyen Van Dan and his co-workers (Hydrogeological Division II, Hanoi) for providing relevant hydrological data and Mai Trong Nhuan (Faculty of Geology, VNU, Hanoi) for helpful discussions. We acknowledge Caroline Stengel, David Kistler, Antonin Mares for analytical assistance, Werner Aeschbach-Hertig and Rolf Kipfer for tritium measurements, Peter Lienemann and Urs Gfeller for WD-XRF measurements, and, Urs von Gunten, Stefan Haderlein, Janet Hering, Eduard Hoehn, Stefan Hug, Annette Johnson, Beat Müller and Laura Sigg for helpful discussions and critical comments on the manuscript. This paper has benefited from four anonymous reviews.

\section{Supporting Information Available}

Three tables showing the results of arsenic in water samples and As, Fe, Mn, TOC, and TON measurements in sediment cores (eight pages). This material is available free of charge via the Internet at http://pubs.acs.org. 


\section{Literature Cited}

(1) Nickson, R.; McArthur, J.; Burgess, W.; Ahmed, K. M.; Ravenscroft, P.; Rahman, M. Nature 1998, 395, 338.

(2) Lepkowski, W. Chem. Eng. News 1998, November 16, 27-29.

(3) McArthur, J. M. Nature 1999, 401, 546-547.

(4) Acharyya, S. K.; Chakraborty, P.; Lahiri, S.; Raymahashay, B. C.; Guha, S.; Bhowmik, A. Nature 1999, 401, 545.

(5) Chowdhury, T. R.; Basu, G. K.; Mandal, B. K.; Biswas, B. K.; Samanta, G.; Chowdhury, U. K., et al. Nature 1999, 401, 545-546.

(6) Lepkowski, W. Chem. Eng. News 1999, December 6, 127-134.

(7) Arsenic contamination of groundwater in Bangladesh. Final Report Summary; Kinniburgh, D. G.; Smedley, P. L., Eds.; Bangladesh Department for Public Health Engineering. British Geological Survey: Keyworth, UK, 2000. http://www.bgs.ac.uk/arsenic

(8) McArthur, J. M.; Ravenscroft, P.; Safiulla, S.; Thirlwall, M. F. Water Resources Res. 2001, 37, 109-117.

(9) Smith, A. H.; Lingas, E. O.; Rahman, M. Bull. World Health Org. 2000, 78, 10931102.

(10) Christen, K., Environ. Sci. Technol., Web Edition. April 2001:

http://pubs.acs.org/journals/esthag/announcements/arsenic.html

(11) Hydrogeological Division II Annual Report 1999; Vietnam Geological Survey: Hanoi, Vietnam, 2000. (in Vietnamese)

(12) Red River Delta Master Plan, Vol. 1 Summary; Government of Vietnam. Ministry of Science, Technology and Environment: Hanoi, Vietnam, 1995.

(13) Water Master Plan of Hanoi City for the Period of 1993-2010. Vol. 1; The Social Republic of Vietnam, Hanoi People's Committee. The Republic of Finland, Finnish International Development Agency FINNIDA: Hanoi, Vietnam, 1993.

(14) Encyclopaedia Britannica. 2001: http://www.britannica $. c o m / e b / a r t i c l e ? e u=64551$

(15) Trafford, J. M.; Lawrence, A. R.; Macdonald, D. M. J.; Nguyen, V. D.; Tran, D. N.; Nguyen, T. H. The effect of urbanisation on the groundwater quality beneath the city of Hanoi, Vietnam. BGS Technical Report WC/96/22; British Geological Survey: Keyworth, UK, 1996.

(16) Mathers, S.; Davies, J.; McDonald, A.; Zalasiewicz, J.; Marsh, S. The Red River delta of Vietnam: A demonstration of the applicability of sedimentology to the investigation of unconsolidated sedimentary aquifers. BGS Technical Report WC/96/02; British Geological Survey: Keyworth, UK, 1996.

(17) Hug, S. J.; Canonica, L.; Wegelin, M.; Gechter, D.; von Gunten, U. Environ. Sci. Technol. 2001, in press.

(18) Beyerle, U.; Aeschbach-Hertig, W.; Imboden, D. M.; Baur, H.; Graf, T.; Kipfer, R. Environ. Sci. Technol. 2000, 34, 2042-2050. 
(19) Dzombak, D. A.; Morel, F. M. M. Surface Complexation Modeling: Hydrous Ferric Oxide; Wiley-Interscience: New York, 1990.

(20) Nickson, R. T.; McArthur, J. M.; Ravenscroft, P.; Burgess, W. G.; Ahmed, K. M. Appl. Geochem. 2000, 15, 403-413.

(21) Peters, S. C.; Blum, J. D.; Klaue, B.; Karagas, M. R. Environ. Sci. Technol. 1999, 33, 1328-1333.

(22) Welch, A. H.; Lico, M. S.; Hughes, J. L. Gound Water 1988, 26, 333-347.

(23) Rodwell, R. J. Appl. Geochem. 1994, 9, 279-286.

(24) Korte, N. E.; Fernando, Q. Crit. Rev. Environ. Control 1991, 21, 1-39.

(25) Brannon, J. M.; Patrick, W. H. Environ. Sci. Technol. 1987, 21, 450-459.

(26) Welch, A. H.; Westjohn, D. B.; Helsel, D. R.; Wanty, R. B. Ground Water 2000, 38, 589-604.

(27) Savage, K. S.; Tingle, T. N.; O'Day, P. A.; Waychunas, G. A.; Bird, D. K. Appl.Geochem. 2000, 15, 1219-1244.

(28) Schreiber, M. E.; Simo, J. A.; Freiberg, P. G. Hydrogeol. J. 2000, 8, 161-176.

(29) Kim, M.-J.; Nriagu, J.; Haack, S. Environ, Sci. Technol. 2000, 34, 3094-3100.

(30) Andersson, L.; Norrman, J. Master's Thesis, Calmers tekniska högskola, Geological Institute. Göteborg, Sweden, 1998.

(31) Zobrist, J.; Dowdle, P. R.; Davis, J. A.; Oremland, R. S. Environ. Sci. Technol. 2000, $34,4747-4753$.

(32) Nguyen, K. N.; Doan, V. C.; Nguyen, V. L.; Nguyen, V. D.; Truong, N. A.; Do, T. B., et al. Investigation and Strategy to Preserve Groundwater Resources in the Hanoi Area; University of Mining and Geology, Department of Hydrogeology: Hanoi, Vietnam, 1997. (in Vietnamese)

(33) Nguyen, V. D.; Koponen, H. Report on Land Subsidence Study 1995 in Hanoi Area; Vietnam Geological Survey, Hydrogeological Division II: Hanoi, Vietnam, 1995.

(34) Tran, M.; Nguyen, T. T. Detailed Investigation of Groundwater in the Hanoi Area; Vietnam Geological Survey, Hydrogeological Division II: Hanoi, Vietnam, 1993. (in Vietnamese)

(35) National Research Council Arsenic in drinking water; National Academic Press: Washington D.C., 1999.

(36) Arsenic Exposure and Health Effects; Chappell, W. R.; Abernathy, C. O.; Calderon, R. L., Eds.; Elsevier Science: Kidlington, Oxford, UK, 1999.

(37) Saha, J. C.; Dikshit, A. K.; Bandyopadhyay, M.; Saha, K. C. Crit. Rev. Environ. Sci. Tech. 1999, 29, 281-313. 


\section{Figure Captions}

Figure 1. Arsenic concentrations in the Hanoi area in September 1999. a, In the rural districts A to D arsenic concentrations were measured in groundwaters pumped from the upper aquifer by private tubewells (dots). b, In the city of Hanoi arsenic concentrations were analyzed in raw groundwater of the lower aquifer and in treated water of the eight major water treatment plants (split rectangles), as well as in tap water of supplied households (dots). The numbers I to VIII refer to the following water treatment plants. I: Mai Dich, II: Ngoc Ha, III: Yen Phu, IV: Ngo Si Lien, V: Luong Yen, VI: Ha Dinh, VII: Tuong Mai, VIII: Phap Van.

Figure 2. Arsenic concentration ranges in raw groundwaters from the lower aquifer and in treated Hanoi waters of eight water treatment plants. Seven sample series were analyzed from April 1999 through July 2000 (7 x 16 samples). The numbers I to VIII of the water works refer to Figure 1. The full database is available as Supporting Information.

Figure 3. Correlation of total arsenic with total iron in sediment layers of five bore cores of July 2000 from districts A-D and urban Hanoi ( $\mathrm{n}=64)$. The 12-40 m deep cores were sampled at 1 or $2 \mathrm{~m}$ intervals. The extreme outlyer marked by an open diamond was associated with a peat layer.

Figure 4. Cumulative frequency distributions of arsenic concentration ranges in groundwaters from the upper aquifer pumped by private tubewells (rural districts) in September 1999, December 1999, and May 2000. The administrative district A, B, C, and D are shown in Figure 1a. Numbers of samples are given in Table 1. 

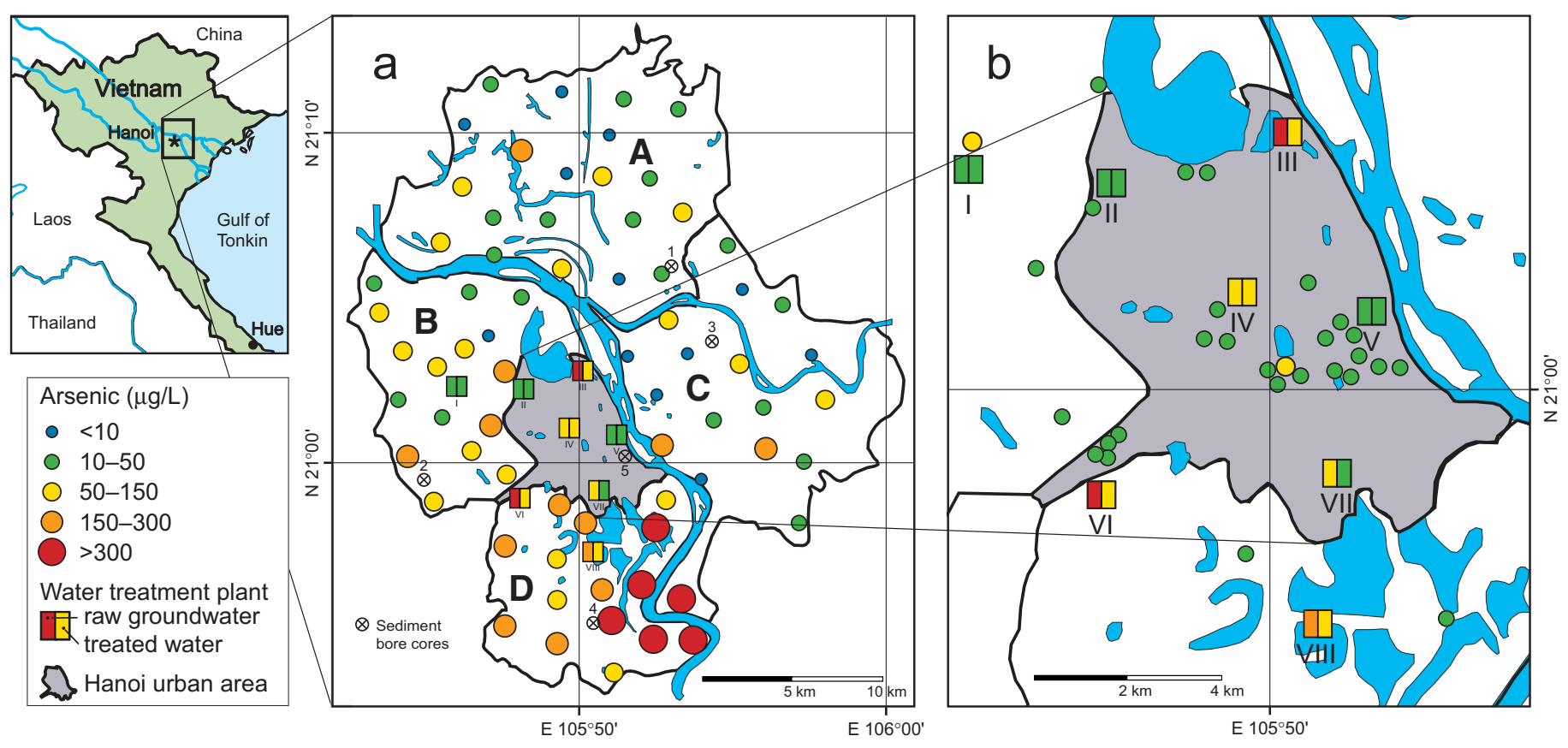

Figure 1, ES010027Y (Berg et al.) 


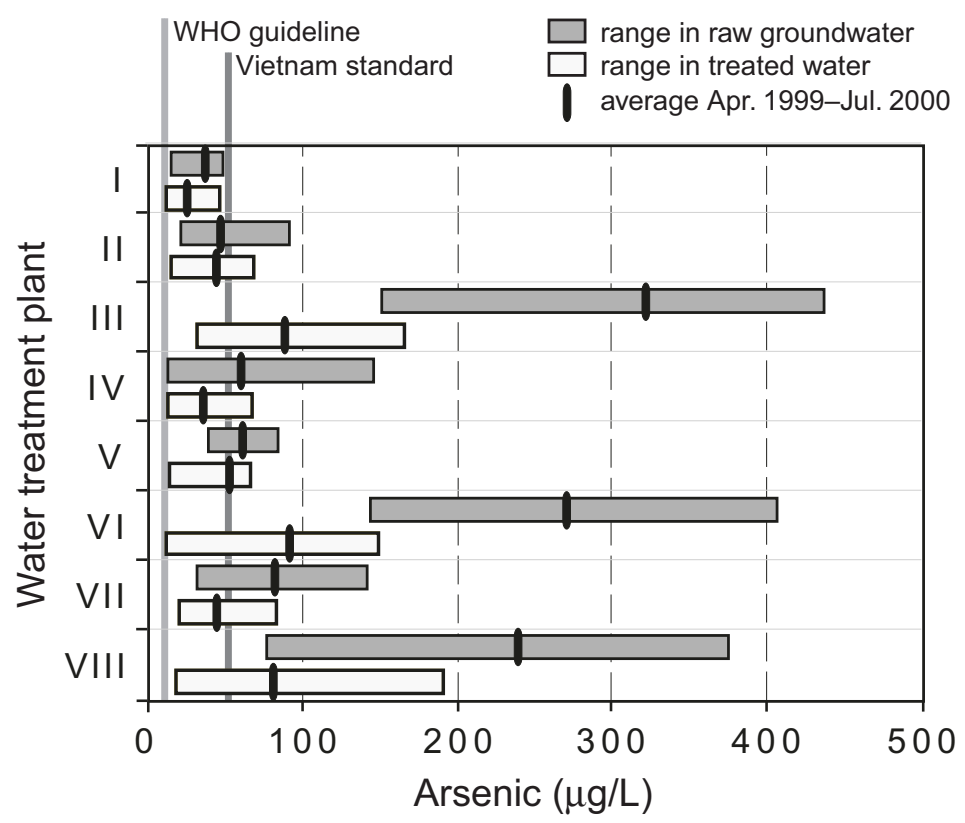

Figure 2, ES010027Y (Berg et al.) 


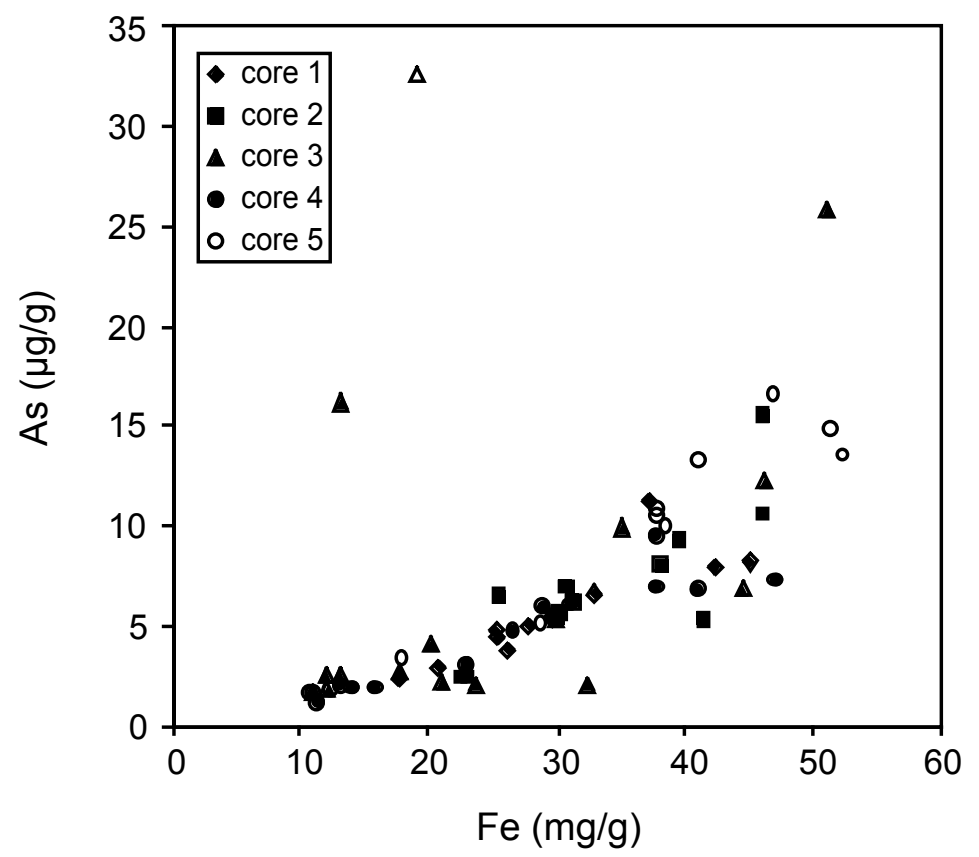

Figure 3, ES010027Y (Berg et al.) 


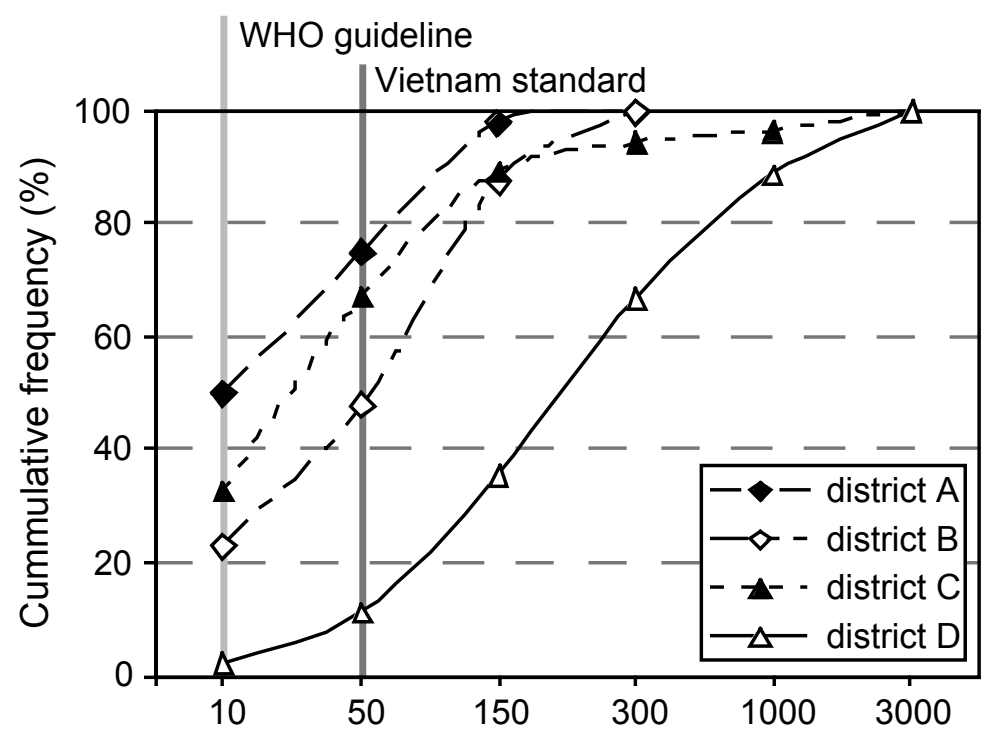

Arsenic concentration ranges ( $\mu \mathrm{g} / \mathrm{L})$

Figure 4, ES010027Y (Berg et al.) 